\title{
Adult emergence order in a community of cavity-nesting bees and wasps, and
}

\section{their parasites}

\author{
J Scott MacIvor
}

Department of Biological Science, University of Toronto Scarborough, 1265 Military Trail, Toronto, Ontario, Canada M1C 1A4

email: scott.macivor@utoronto.ca

phone: +1-416-208-8191 


\begin{abstract}
Evaluating resource use and overlap through time and space among and within species having similar habitat requirements informs community-level conservation and coexistence, efforts to monitor species at-risk and biological invasions. Many species share common nesting requirements; one example are cavity-nest bees and wasps, which provision nests in dark and dry holes in wood, plant stems, or other plant-based materials that can be bundled together into 'trap nests'. In this study, the adult emergence order of 47 species of solitary cavity-nesting bees and wasps, and their parasites (total $\mathrm{N}>8000$ brood cells) were obtained from two hundred identical trap nests set up each year (over three years) to survey these populations across Toronto, Canada and the surrounding region. All brood cells collected were reared in a growth chamber under constant warming temperature and humidity to determine species identity, and adult emergence order. This order ranged from 0 to 38 days, with all mason bees (Osmia spp.) emerging within the first two days, and the invasive resin bee species, Megachile sculpturalis Smith significantly later than all others. Late emerging species i) exhibited significantly greater intraspecific variation in mean emergence day and ii) were significantly larger in body size, compared to early emerging species. Detailing natural history information at the species- and community-level, such as the adult emergence order of coexisting cavity-nesting bees and wasps and their parasites, can inform the timing of deployment of trap nests to support and monitor target species, and refine experimental design to study these easily-surveyed and essential insect communities.
\end{abstract}

Keywords: Hymenoptera; Osmia; Megachile; nest box; trap nest; interspecific variation; niche partitioning; host-parasite interactions 


\section{Introduction}

Interspecific partitioning in the timing of similar, critical life-history stages is an evolutionary adaptation used to minimize resource overlap and competition among species (Richards 1927; Schoener 1974; Albrecht and Gotelli 2001; Martin et al. 2004; Taylor et al. 2014). For example, many nest provisioning solitary bee and wasp species share similar nesting location preferences, yet have evolved to partition these resources in order to coexist in time (Wcislo and Cane 1996; Hoehn et al. 2008) and space (Willmer and Corbet 1981; Tylianakis et al. 2005). Intraspecific variation at these critical life-history stages can also be important in determining fitness among individuals within the same species (Bolnick et al. 2011). Variation in emergence from nests as adults may be linked to evolutionary adaptations to local environmental conditions that optimize reproductive and foraging success. In temperate regions, solitary bees and wasps are active for short overlapping periods in a season, which are linked to the availability of preferred resources (Lindsey 1958; Minckley et al. 1994; Leong and Thorp 1999). The remainder of the year is spent as an immature in a nest constructed by the mother (with some exceptions).

Considerable information is available from field and laboratory studies on the lifecycle, incubation period, and adult emergence order of specific solitary bee species managed for pollination in agriculture, such as Osmia lignaria Say (Bosch et al. 2000), Osmia cornifrons (Radoszkowski) (White et al. 2009), or Megachile rotundata (Fabricius) (Tepedino and Parker 1986). However, there are relatively little data on community-wide adult emergence order or knowledge of intraspecific variation in emergence order of most coexisting solitary bees, and especially wasps, many of which are important predators in biological communities (Budrienè et al. 2004; Forrest and Thomson 2011; Fründ et al. 2013). Many solitary bee and wasp species provision nests in cavities above ground (e.g. pithy or hollowed out plant stems, beetle-bored 
holes in wood), hereafter 'cavity-nesting bees and wasps' (Stephen and Osgood 1965; Bohart 1972; Williams et al. 2010). For many cavity-nesting species, artificial nests that represent the natural nesting conditions can be made by gathering 'nesting tubes' (e.g. drilled holes in wood, plant stems, or paper cardboard tubes) together, commonly referred to as 'trap nests' (Figure 1) (Krombein 1967). Trap nests are widely used to survey cavity-nesting bees and wasps, and their parasites, which include cleptoparasitic bees and wasps, as well as parasitoid wasps, flies, and beetles (Tscharntke et al. 1998; Praz et al. 2008; MacIvor 2017). Identifying nests occurring naturally in the landscape is time consuming and difficult to retrieve in sufficient numbers needed for experiments. On the other hand, rearing cavity-nesting bees and wasps, and their parasites to adulthood from individuals obtained from nesting tubes in trap nests is a useful way to identify species-level interactions and community-level patterns at a local or landscape scale (Staab et al. 2018). Many other studies utilize trap nests to evaluate relationships between species diversity and resource utilization, and in response to environmental change (Yocum et al. 2005; Sheffield et al. 2008; O’Neill et al. 2011; Fliszkiewicz et al. 2012; Fründ et al. 2013). There are applications as well; for example, to support species of concern, the addition of foraging plants (Sheffield et al. 2008) or accelerate the release of bees reared on mass to synchronize with target crops (Bosch et al. 2000). 


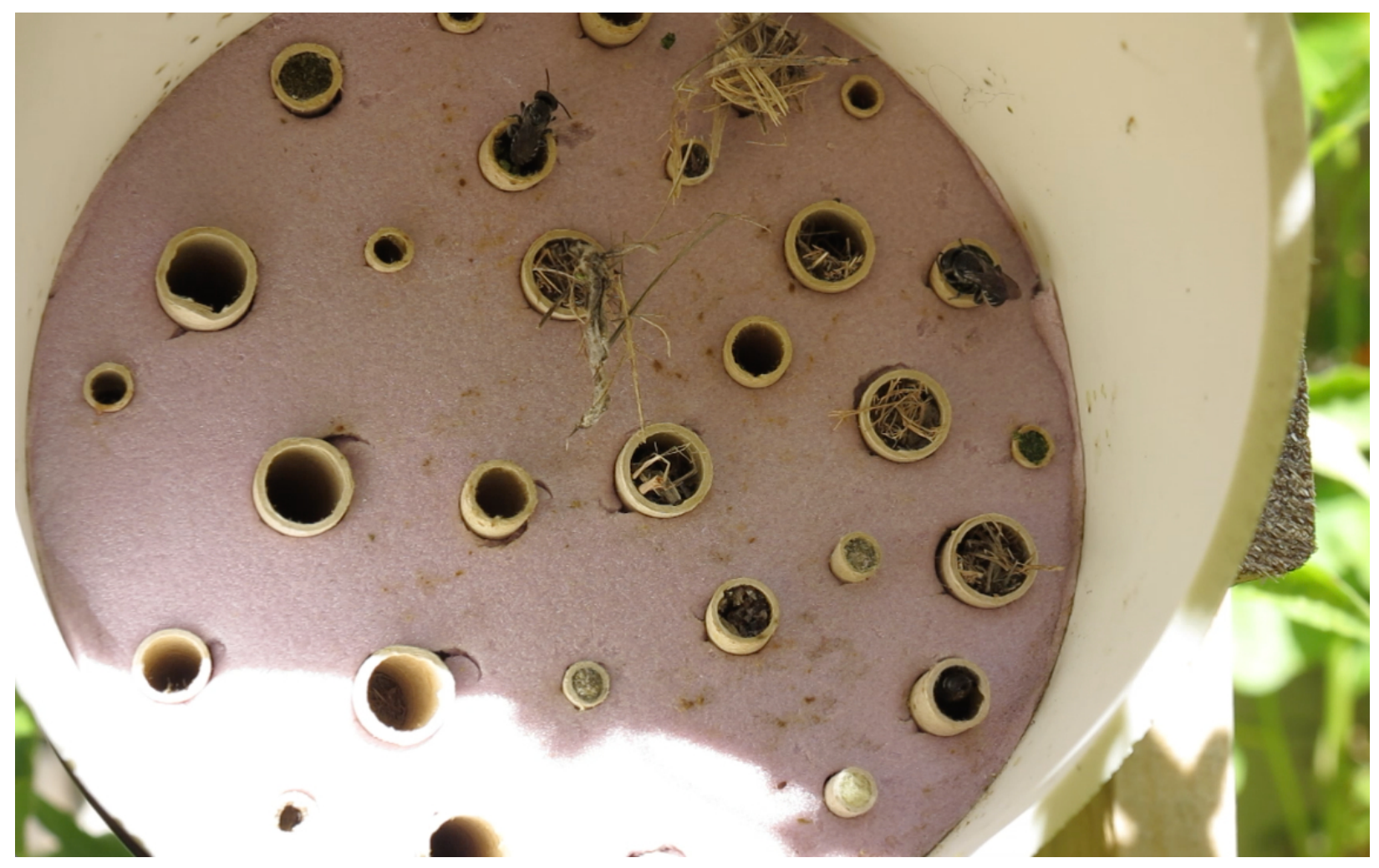

Figure 1. A trap nest used to study cavity-nesting bees and wasps. The cardboard paper 'nesting tubes' are inserted into a piece of pink insulation board fitted into a white PVC pipe for support and protection from rain.

In this study, the adult emergence order among and within 47 coexisting species of cavity-nesting bees and wasps, and their parasites were quantified from individuals obtained from trap nests and reared in a laboratory setting at constant temperature and humidity, to represent a spring warming period. The main objective was to map emergence order in this community of cavity-nesting bees and wasps, and their parasites to improve management of these important taxa, for example, to 1) support an abundance of target species, 2) aid in the detection of invasive species, or 3) monitor host-parasite interactions as environmental indicators.

Using these data, I also evaluate two hypotheses. First, that intraspecific variation in 
emergence time will increase in late emerging species because they incubate longer than early emerging species, and fluctuations in the environment can affect development time (O'Neill et al. 2011). Second, although Bosch and Kemp (2002) noted no relationship between intraspecific body size and adult emergence in the European Orchard bee, Osmia cornuta, I predicted body size differences between species in the bee and wasp community would affect interspecific adult emergence order, with larger bodied species emerging significantly later than smaller bodied species, because body size is generally correlated with development time to adult (Garcia-Barros, 2000).

\section{Methods}

The cavity-nesting bees and wasps, and their parasites examined here were obtained from a survey of 200 trap nests set up each year (one per site) from May to October for three years (2011-2013) throughout the city of Toronto and surrounding region. The sites were a minimum $250 \mathrm{~m}$ apart and spread over an area encompassing approximately $745 \mathrm{~km}^{2}$. Trap nests were made of white PVC piping that was $10 \mathrm{~cm}$ in diameter and $28 \mathrm{~cm}$ in length, a circular faceplate made of insulation board into which 30 cardboard nesting tubes (Custom Paper Tubes, Cleveland, OH) were inserted (10 of each of three tube diameters; $3.4 \mathrm{~mm}, 5.5 \mathrm{~mm}, 7.6 \mathrm{~mm}$; all $15 \mathrm{~cm}$ in length) at one end, and the opposite end was blocked with a PVC pipe cap (Figure 1). Each year, in October, trap nests were collected, each cardboard nesting tube opened, and every brood cell removed. The contents of each brood cell were labeled with a unique identifier and placed into individual cells within 24-cell assay trays with the lid on. A complete incubation process includes a sufficiently long cooling period (Bosch and Kemp 2004), and so all specimens spent the cold season (October - March) in a walk-in fridge kept at a constant $4^{\circ} \mathrm{C}$ (as in Bosch et al. 2000). 
At the end of the cold season, in early April the following year, the assay trays containing all brood cells from the previous year were moved from the walk-in fridge to a sealed growth chamber where temperature and humidity were held constant at $26^{\circ} \mathrm{C}$ and $60 \%$ (Johansen and Eves 1973; Tepedino and Parker 1986). All species overwintered as prepupae (mature postdefecated larvae) except for mason bees (Osmia spp.), and a parasite wasp of Osmia (Sapyga centrata Say) which overwinter as adults. The growth chamber was windowless and kept dark for the duration of the study except when lights were turned on during daily inspection of brood cells to measure adult emergence order (as in Sheffield et al. 2008). Approximately 3\% of all cells in the growth chamber were lost to parasitic wasps (Melittobia chalybii Ashmead and Monodontomerus obscurus Westwood) wasps that emerged early and attacked other larvae still undergoing development. To reduce their depredations, four traps, each consisting of a black light and a bowl filled with water and dish soap, were set up to attract and reduce the number of these minute wasps that emerged and escaped the assay tray (Eves et al. 1980). For each individual bee, wasp, or parasite, the time to emergence was recorded as the number of days from the start of warming (e.g. onset of the incubation period) to the time of development to adulthood and emergence from the cocoon (Owen and McCorquodale 1994; Sheffield et al. 2008). After the three-year survey, a total of 84 species of bee, wasp, and parasite were identified (MacIvor and Packer 2015), but emergence day was recorded for only those species with 5 or more successfully emerged adults with timing accurately recorded, and so 47 species and 8,006 individuals were used for this study (Figure 2). All bees, wasps, and parasites were identified using the collections from the Packer Lab at York University and the Marshall Lab at University of Guelph. All specimens are kept in the MacIvor Lab at University of Toronto Scarborough.

An analysis of variance $(\alpha=0.05)$ was used to determine if there was a significant 
difference in interspecific adult emergence order (in days post onset of incubation) among the cavity-nesting bees and wasps, and their parasites. Given my objectives, all males and females per species were grouped together; even though males emerge on average slightly earlier than females, both sexes emerge near the same time to ensure reproduction. A tukey-post hoc analysis was then conducted to evaluate significant differences among species of bee, wasp, and parasite. A Pearson's R correlation was used to examine whether the intraspecific variation in emergence day, as determined by the standard error of the mean, increased with increasing mean emergence day across the community. Finally, the intertegular (IT) span (Cane 1987; Greenleaf et al. 2007; Williams et al. 2010) was measured (in mm) using an ocular micrometer attached to a dissecting microscope on a sample of 5-10 individuals per species and a linear regression was used to compare IT and mean emergence day among all species. All statistics were completed using the R statistical program v3.2.2 (R Core Team 2015).

\section{Results}

Of the 47 species examined, there were 22 species and six genera of bee in two families (all in the superfamily Apoidea). These included bees in the genus, Hylaeus (Colletidae), as well as Osmia, Heriades, Hoplitis, Chelostoma, Megachile (all Megachilidae). There were 16 species of cavity-nesting wasp in nine genera and four families, these included Isodontia (Sphecidae), Passaloecus, Psenulus and Trypoxylon (Crabronidae), as well as Ancistrocerus, Euodynerus, Symmorphus (Vespidae), and Auplopus and Dipogon (Pompilidae) (Figure 2). Nine species in seven genera and 5 families of parasites were identified from three orders (Hymenoptera, Coleoptera, Diptera), and parasites, Ephialtes manifestator (Linnaeus) and Anthrax irroratus Say had more than one host (Table 1). 

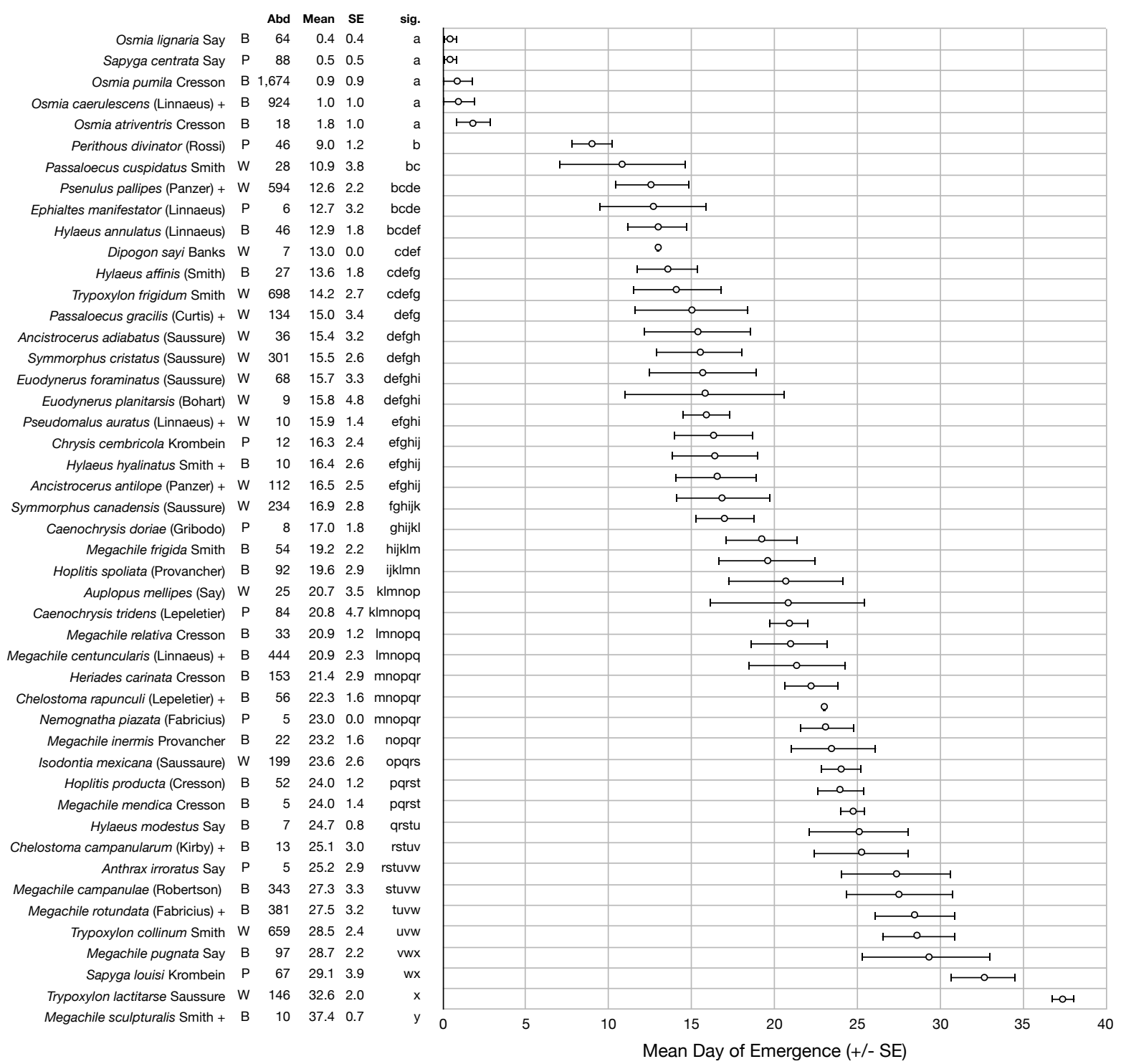

Figure 2. Variation in the mean emergence time for species of bee, wasp, and parasite recorded from individuals taken from trap nests. 'Taxa' denotes cavity-nesting bees (B), cavity-nesting wasps (W), and parasites (P). 'Abd' is the total number of individuals incubated and emerged successfully. 'Mean' is the average number of days taken to emerge and 'SE' is the standard error of the mean. Significant differences between species ('sig') were given alphabetically where species sharing a letter were not significantly different from one another $(\alpha=0.05)$. Those species denoted with a "+" are considered introduced to the region.

Interspecific mean emergence day (e.g. number of incubation days to adulthood) among all 47 species was significantly different $\left(\mathrm{F}_{47}=786.29, \mathrm{p}<0.001\right)$ and ranged from 0 to 38 (Figure 
2). Many significant differences were noted. For example, the data confirmed one anticipated pattern, that mason bees (Osmia spp.) emerge significantly earlier than all others because they overwinter as adults (Fye 1965; Bosch et al. 2001) (Figure 2). The invasive large resin bee, Megachile sculpturalis, was the largest species recorded in this study and emerged significantly later than all other species (average emergence day $=37.4 \pm 0.7$ days; mean $\pm \mathrm{SE}$ ) (Figure 2 ). The greatest overlap (e.g. average emergence day did not differ significantly) occurred between day 12 and 17, when 15 species (three cavity-nesting bees, ten cavity-nesting wasps, and two parasites) emerged (Figure 2).

Parasites had significantly higher variation in adult emergence than both cavity-nesting bees and wasps $\left(\mathrm{F}_{2}=4.190, \mathrm{p}=0.021\right)$. The difference in the mean emergence day between parasite and host varied depending on the parasite species. For example, the parasitic fly, $A$. irroratus emerged on average 25 days after its host, whereas emergence day of three cuckoo wasps were more similar to that of their host: on average, Chrysis cembricola Krombein emerged on the same day as Symmorphus canadensis (de Saussure), Caenochrysis doriae (Gribodo) emerged 2.8 days later than its host Trypoxylon frigidum Smith, and Caenochrysis tridens (Lepeletier) emerged 7.7 days earlier than its host Trypoxylon collinum Smith (Figure 2). Late emerging species exhibited greater intraspecific variation in emergence day. A Pearson's R correlation showed there was a significantly positive correlation between mean and variation in emergence time (Figure 3). Finally, the average emergence time was positively correlated with body size when all 47 species were included in a linear regression analysis (Figure 4). 


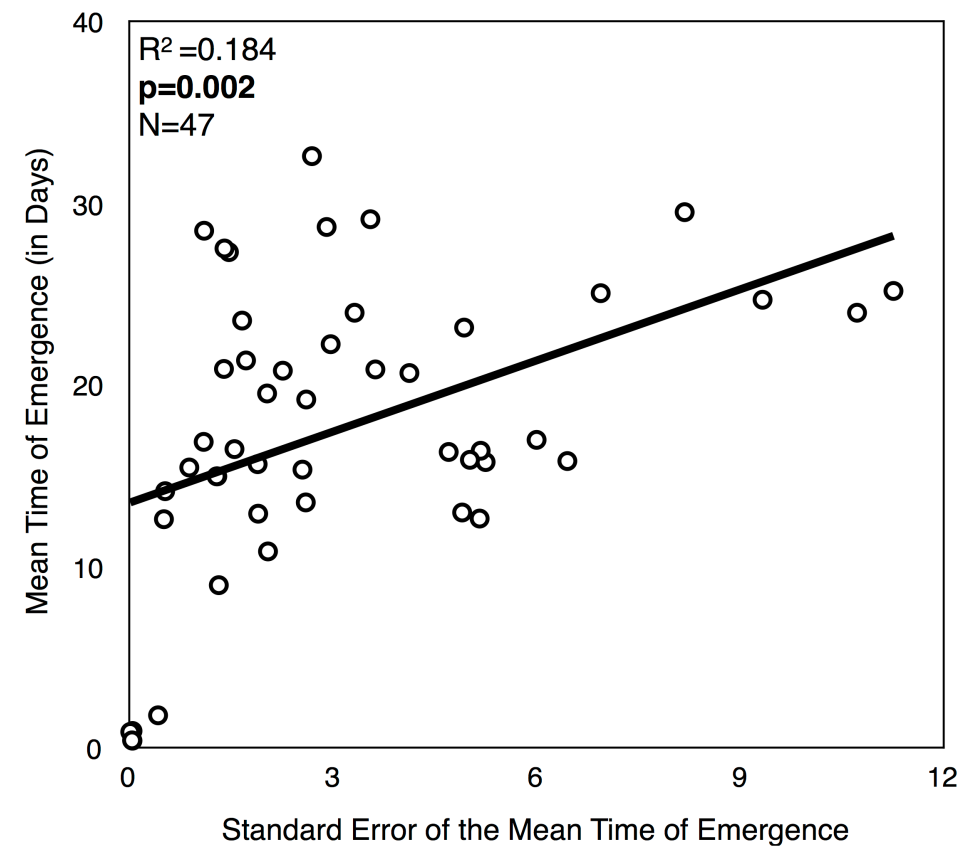

Figure 3. Scatterplot illustrating a significantly positive community-wide correlation between intraspecific mean and variation in emergence time.

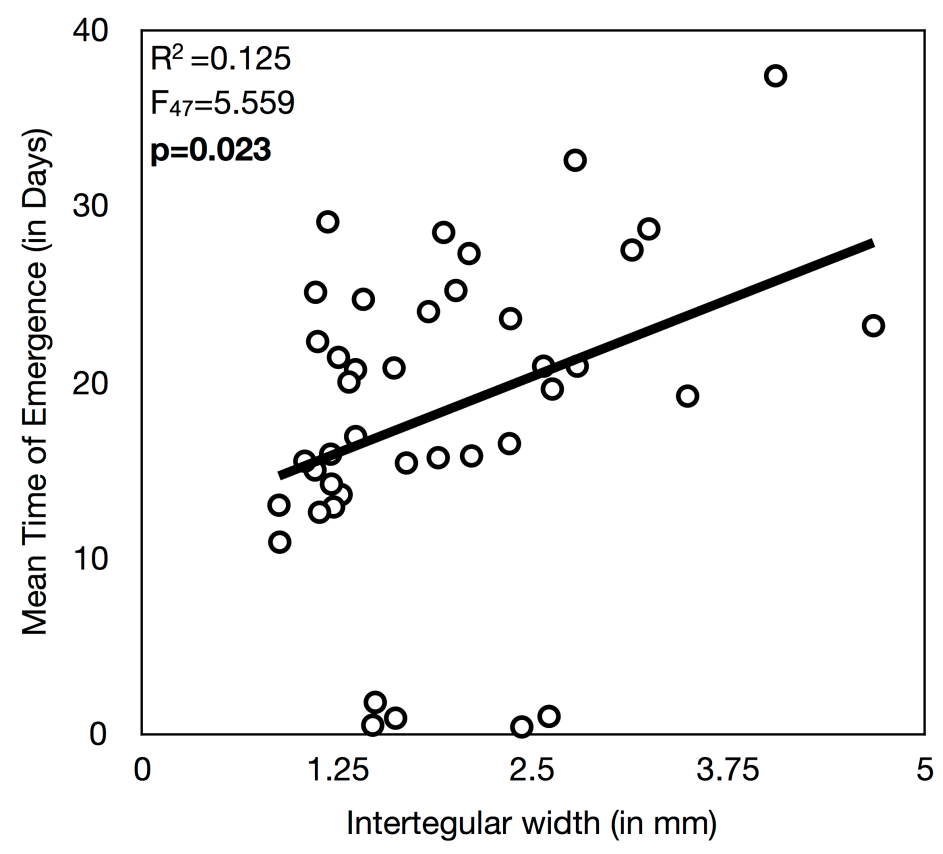

Figure 4. Scatterplot showing the significant relationship between mean emergence time and body size as measured by the intertegular width. 


\section{Discussion}

There was a significant interspecific difference in average emergence day among the 47 species of cavity-nesting bees and wasps, and their parasites evaluated. There was evidence to support both hypotheses, that 1) there would be greater intraspecific variation in emergence day in late emerging species compared to early emerging species, and 2) late emerging species would be the largest in body size. Interpreting overlap in emergence time can inform basic knowledge of their species in communities, but also indirectly, potential competition for nesting resources at trap nests. These findings can also support action to enhance target species that use trap nests, by, for example, precisely-timed placement of trap nests in landscapes to increase populations of some species over others.

Bees in the genus Osmia and one specialist parasite of $O$. pumila Cresson, the wasp Sapyga centrata, emerged significantly earlier than all other species (Figure 2). They become active at the start of spring and this life-history strategy greatly narrow the variation in adult emergence (Figure 3). The remaining bees, wasps, and parasite species use warming temperatures as a cue to initiate transition from pupa to adult, a process which is subject to variation in time to completion due to environmental changes (Tepedino and Parker, 1986; Kemp and Bosch, 2014). Between day 12 and 17 there was an overlap in the mean emergence day among ten cavity-nesting wasp species (Figure 2). These wasp species are each predators of a different group of invertebrates, for example, spiders (Trypoxylon; Medler 1967), caterpillars and beetle larvae (Symmorphus; Cowan 1981), or aphids (Passoloecus; Fricke 1993). Since these wasps were similarly sized, competition for nesting locations in this community could be a more limiting resource than prey opportunities (Wcislo 1996; Potts et al. 2005).

Interspecific body size was positively correlated with mean emergence time and this 
agrees with other comparative studies that show larger insects take longer to develop (Kingsolver and Huey, 2008). Cavity-nesting bees and wasps select nesting locations with inner widths that are closest to their own body width, and so recording interspecific intertegular widths within a community (see Figure 2) can help practitioners decide on nesting tube dimensions when implementing trap nests to target specific species of interest and known body sizes (Lee-Mäder et al. 2010). Late emerging species exhibited greater intraspecific variation than early emerging species (Figure 3). Being larger can confer a number of benefits; for example, larger bodied solitary bee species can carry more pollen (e.g. Kendall and Soloman 1973) and larger wasps can carry larger prey (e.g. O’Neill 1985; Coelho 1997). However, longer periods of time as prepupae in a nest could increase mortality by parasitism or predation (Stearns and Koella 1986; Blanckenhorn 2000).

The tropical-in-origin and invasive bee, Megachile sculpturalis, was the largest species recorded, and the latest to emerge from the nest (Mangum and Sumner 2003). This bee is known to attack and replace a native bee, Xylocopa virginica (Linnaeus) (Roulston and Malfi 2012), and likely others coexisting at trap nests. Since M. sculpturalis uses tree resins similar to one desirable native bee, M. campanulae (Robertson) which emerges significantly earlier (day=27.2 \pm 3.3 ), M. sculpturalis can be quickly identified and removed due to this $10+$ day difference in emergence time. Knowledge of emergence timing within a community of trap nesting bees and wasps can therefore finetune temporal applications of strategies for supporting target species such as monitoring and removal of invasive species.

Parasite-host association and diversity can inform understanding of parasites as indicators of habitat quality and community-level change (Sheffield et al. 2013). Some authors have noted that parasites are synchronized with hosts and emerge slightly later relative to them (Thorp et al. 
1983; Baker et al. 1985). These parasites are typically those that attack larva and so emerging after the host ensures host prey is available. For example, in this study the parasitoid Anthrax irroratus attacked two Osmia species and emerged 25 days after both hosts, at which point he Osmia females had mated and begun to build nests containing the next generation (Table 1). Scott and Strickler (1992) also recorded A. irroratus emerging one month after its hosts, Megachile relativa Cresson and $M$. inermis Provancher. The parasite larvae develop on the prepupae of the bee host after hatching from a tiny egg 'flicked' indiscriminately into the nest by the fly as she hovers in front of the nest entrance (Minckley 1989). Each fly larvae overwinter and develop to adults in the spring (Gerling and Hermann 1976). Cleptoparasites on the other hand replace the host egg with their own, or their early instar larvae kill the host egg or larva, and so have an emergence time that is more similar to that of the host (Forrest and Thomson 2011). In this study, cleptoparasites included Chrysis cembricola, Caenochrysis doriae and Caenochrysis tridens, which all emerged within a week of their host (Figure 2).

Documenting the identity and adult emergence order of coexisting solitary bees, wasps, and parasites in communities can provide significant information about competition and niche overlap in these important and ecologically similar taxa (Frankie et al. 1998; Tscharntke et al. 1998; Bosch and Kemp 2002; Tylianakis et al. 2007; Forrest and Thomson 2011). One limitation of this study is that the emergence times were recorded based on controlled post-incubation temperature and humidity. More work is needed to examine adult emergence of feral populations of solitary bees and compare patterns to those obtained from controlled settings (O'Neill et al. 2010).

Solitary cavity-nesting bees and wasps, that i) compete for a common nesting resource, ii) readily use artificial trap nests, and iii) easily managed by practitioners and citizens intent on 
enhancing their populations and services they provide, are excellent model organisms for community ecology research, conservation, and outreach with the public on their importance (Lee-Mäder et al. 2010; Colla and MacIvor 2017). These data on interspecific overlap in nesting resources can improve initiatives for pollination service management, and a growing number that are interested in enhancing pest-controlling wasps. Interpreting adult emergence order and overlap in trap nest communities can also support conservation, for example, by knowing when to replace nest tubes with fresh empty ones to ensure adequate supply over the season (MacIvor 2017), or for monitoring invasive species requiring control (Barthell et al. 1998). Trap nests provide a wealth of information on these communities, and so should be in the toolbox of conservation scientists and practitioners working with these critically important insects. 


\section{Acknowledgements}

Thanks to Baharak Salehi and Jen Albert for help with the incubation and rearing, also Dr.

Laurence Packer and Charlotte de Keyzer for useful comments on the manuscript. Funding was

provided by an NSERC-CGS (CGS D 408565) awarded to the first author, and an NSERC

discovery grant awarded to the supervisor Dr. Laurence Packer. 


\section{References}

Albrecht M, Gotelli NJ (2001) Spatial and temporal niche partitioning in grassland ants.

Oecologia 126: 134-141.

Baker JR, Kuhn ED, Bambara SB (1985) Nests and immature stages of leafcutter bees

(Hymenoptera: Megachilidae). Journal of the Kansas Entomological Society 58: 290-313.

Barthell JF, Frankie GW, Thorp RW (1998) Invader effects in a community of cavity nesting

megachilid bees (Hymenoptera: Megachilidae). Environmental Entomology 27: 240-247.

Blanckenhorn WU (2000) The evolution of body size: What keeps organisms small?. Quarterly

Review of Biology 75: 385-407.

Bohart GE (1972) Management of wild bees for the pollination of crops. Annual Review of

Entomology 17: 287-312.

Bolnick DI, Amarasekare P, Araújo MS, Bürger R, Levine JM, Novak M, Ruolf VHW,

Schreiber SJ, urban MC, Vasseur, DA (2011) Why intraspecific trait variation matters in community ecology. Trends in Ecology \& Evolution, 26: 183-192.

Bosch J, Kemp WP, Peterson SS (2000) Management of Osmia lignaria (Hymenoptera:

Megachilidae) populations for almond pollination: Methods to advance bee emergence.

Environmental Entomology 29: 874-883.

Bosch J, Maeta Y, Rust R (2001) A phylogenetic analysis of nesting behavior in the genus

Osmia (Hymenoptera: Megachilidae). Annals of the Entomological Society of America 94:

$617-627$.

Bosch J, Kemp WP (2002) Developing and establishing bee species as crop pollinators: The example of Osmia spp. (Hymenoptera: Megachilidae) and fruit trees. Bulletin of Entomological Research 92: 3-16. 
Bosch J, Kemp WP (2004) Effect of pre-wintering and wintering temperature regimes on weight loss, survival, and emergence time in the mason bee Osmia cornuta (Hymenoptera: Megachilidae). Apidologie 35: 469-479.

Budrienė A, Budrys E, Nevronytė Ž (2004) Solitary Hymenoptera Aculeata inhabiting trap-nests in Lithuania: Nesting cavity choice and niche overlap. Latvijas Entomologs 41: 19-31.

Cane JH (1987) Estimation of bee size using intertegular span (Apoidea). Journal of the Kansas Entomological Society 60: 145-147.

Coelho JR (1997) Sexual size dimorphism and flight behavior in cicada killers, Sphecius speciosus. Oikos 79: 371-375.

Colla SR, MacIvor JS (2017) Questioning public perception, conservation policy, and recovery actions for honeybees in North America. Conservation Biology 31: 1202-1204.

Cowan DP (1981) Parental investment in two solitary wasps Ancistrocerus adiabatus and Euodynerus foraminatus (Eumenidae: Hymenoptera). Behavioral Ecology and Sociobiology 9: 95-102.

Eves JD, Mayer DF, Johansen CA (1980) Parasites, predators and nest destroyers of the alfalfa leafcutting bee, Megachile rotundata. Washington State University, Agricultural Experiment Station, Western Regional Extension Publication vol. 32) 15: 1-15.

Fliszkiewicz M, Kuśnierczak A, Szymaś B (2012) The accompanying fauna of solitary bee Osmia bicornis (L.) syn. Osmia rufa (L.) nests settled in different biotopes. Journal of Apicultural Science 56: 51-58.

Forrest JR, Thomson JD (2011) An examination of synchrony between insect emergence and flowering in Rocky Mountain meadows. Ecological Monographs 81: 469-491. 
Frankie GW, Thorp RW, Newstrom-Lloyd LE, Rizzardi MA, Barthell JF, Griswold TL, Kim JY, Kappagoda S (1998) Monitoring solitary bees in modified wildland habitats: Implications for bee ecology and conservation. Environmental Entomology 27: 1137-1148.

Fricke JM (1993) Aphid prey of Passaloecus cuspidatus (Hymenoptera: Sphecidae). Great Lakes Entomologist 26: 31-35.

Fründ J, Dormann CF, Holzschuh A, Tscharntke T (2013) Bee diversity effects on pollination depend on functional complementarity and niche shifts. Ecology 94: 2042-2054.

Fye RE (1965) Biology of Apoidea taken in trap nests in northwestern Ontario (Hymenoptera). The Canadian Entomologist 97: 863-877.

Garcia-Barros E (2000) Body size, egg size, and their interspecific relationships with ecological and life history traits in butterflies (Lepidoptera: Papilionoidea, Hesperioidea). Biological Journal of the Linnean Society 70: 251-284.

Gerling D, Hermann H (1976) The oviposition and life cycle of Anthrax tigrinus [Dipt.: Bombyliidae] a parasite of carpenter bees [Hym.: Xylocopidae]. Entomophaga 21: 227233.

Greenleaf SS, Williams NM, Winfree R, Kremen C (2007) Bee foraging ranges and their relationship to body size. Oecologia 153: 589-596.

Harris AC (1994) Ancistrocerus gazella (Hymenoptera: Vespoidea: Eumenidae): A potentially useful biological control agent for leafrollers Planotortrix octo, P. excessana, Ctenopseustis obliquana, C. herana, and Epiphyas postvittana (Lepidoptera: Tortricidae) in New Zealand. New Zealand Journal of Crop and Horticultural Science 22: 235-238. 
Hoehn P, Tscharntke T, Tylianakis JM, Steffan-Dewenter I (2008) Functional group diversity of bee pollinators increases crop yield. Proceedings of the Royal Society B: Biological Sciences 275: 2283-2291.

Johansen CA, Eves JD (1973) Effects of chilling, humidity and seasonal conditions on emergence of the alfalfa leafcutting bee. Environmental Entomology 2: 23-26.

Kemp WP, Bosch J (2014) Postcocooning temperatures and diapause in the alfalfa pollinator Megachile rotundata (Hymenoptera: Megachilidae). Annals of the Entomological Society of America 94: 244-250.

Kendall DA, Solomon ME (1973) Quantities of pollen on the bodies of insects visiting apple blossom. Journal of Applied Ecology 10: 627-634.

Kingsolver JG, Huey RB (2008) Size, temperature, and fitness: three rules. Evolutionary Ecology Research 10: 251-268.

Krombein KV (1967) Trap-nesting wasps and bees: Life histories, nests, and associates. Smithsonian Institutional Press, Washinton D.C.

Lee-Mäder E, Spivak M, Evans E (2010) Managing alternative pollinators: A handbook for beekeepers, growers, and conservationists. Sustainable Agriculture Research and Education Handbook (vol. 11): NRAES-186.

Leong J, Thorp RW (1999) Colour-coded sampling: The pan trap colour preferences of oligolectic and nonoligolectic bees associated with a vernal pool plant. Ecological Entomology 24: 329-335.

Lindsey EG (1958) The ecology of solitary bees. Hilgardia 27: 543-599.

MacIvor JS, Packer L (2015) Bee Hotels' as tools for native pollinator conservation: A premature verdict?. PLoS-One 10: e0122126. 
MacIvor JS (2017) Cavity-nest boxes for solitary bees: A century of design and research. Apidologie 48: 311-327.

Mangum WA, Sumner S (2003) A survey of the North American range of Megachile

(Callomegachile) sculpturalis, an adventive species in North America. Journal of the Kansas Entomological Society 76: 658-662.

Martin K, Aitken KE, Wiebe KL (2004) Nest sites and nest webs for cavity-nesting communities in interior British Columbia, Canada: Nest characteristics and niche partitioning. The Condor 106: 5-19.

Medler JT (1967) Biology of Trypoxylon in trap nests in Wisconsin (Hymenoptera: Sphecidae). American Midland Naturalist 78: 344-358.

Michener CD (2007) The bees of the world. 2nd. Ed. Johns Hopkins University Press, Baltimore. Minckley RL (1989) Host records and biological notes for two Anthrax species in Arizona (Diptera: Bombyliidae). Journal of the Kansas Entomological Society 62: 274-278.

Minckley RL, Wcislo WT, Yanega D, Buchmann SL (1994) Behavior and phenology of a specialist bee (Dieunomia) and sunflower (Helianthus) pollen availability. Ecology 75: 1406-1419.

O'Neill KM (1985) Egg size, prey size, and sexual size dimorphism in digger wasps

(Hymenoptera: Sphecidae). Canadian Journal of Zoology 63: 2187-2193.

O'Neill KM, Pearce AM, O'Neill RP, Miller RS (2010) Offspring size and sex ratio variation in a feral population of alfalfa leafcutting bees (Hymenoptera: Megachilidae). Annals of the Entomological Society of America 103: 775-784. 
O'Neill KM, O'Neill RP, Kemp WP, Delphia CM (2011) Effect of temperature on post-wintering development and total lipid content of alfalfa leafcutting bees. Environmental Entomology, 40: 917-930.

Owen RE, McCorquodale DB (1994) Quantitative variation and heritability of postdiapause development time and body size in the alfalfa leafcutting bee (Hymenoptera: Megachilidae). Annals of the Entomological Society of America 87: 922-927.

Potts SG, Vulliamy B, Roberts S, O'Toole C, Dafni A, Ne'eman G, Willmer P (2005) Role of nesting resources in organising diverse bee communities in a Mediterranean landscape. Ecological Entomology 30: 78-85.

Praz CJ, Müller A, Dorn S (2008) Host recognition in a pollen-specialist bee: evidence for a genetic basis. Apidologie 39: 547-557.

R Core Team (2015) R: A language and environment for statistical computing. R Foundation for Statistical Computing, Vienna, Austria. URL http://www.R-project.org/.

Richards OW (1927) The specific characters of the British bumblebees (Hymenoptera). Transactions of the Entomological Society of London 75: 233-268.

Roulston TA, Malfi R (2012) Aggressive eviction of the eastern carpenter bee (Xylocopa virginica (Linnaeus)) from its nest by the giant resin bee (Megachile sculpturalis Smith). Journal of the Kansas Entomological Society 85: 387-388.

Schoener TW (1974) Resource partitioning in ecological communities. Science 185: 27-39.

Scott VL, Strickler K (1992) New host records for two species of Anthrax (Diptera:

Bombyliidae). Journal of the Kansas Entomological Society 65: 393-402. 
Sheffield CS, Kevan PG, Westby SM, Smith RF (2008) Diversity of cavity-nesting bees

(Hymenoptera: Apoidea) within apple orchards and wild habitats in the Annapolis Valley,

Nova Scotia, Canada. The Canadian Entomologist 140: 235-249.

Sheffield CS, Pindar A, Packer L, Kevan PG (2013) The potential of cleptoparasitic bees as indicator taxa for assessing bee communities. Apidologie 44: 501-510.

Spivak M, Mader E, Vaughan M, Euliss Jr NH (2010) The plight of the bees. Environmental Science \& Technology 45: 34-38.

Staab M, Pufal G, Tscharntke T, Klein AM (2018) Trap nests for bees and wasps to analyse trophic interactions in changing environments-A systematic overview and user guide. Methods in Ecology and Evolution 9: 2226-2239.

Stearns SC, Koella JC (1986) The evolution of phenotypic plasticity in life-history traits:

Predictions of reaction norms for age and size at maturity. Evolution 40: 893-913.

Stephen WP, Osgood CE (1965) Influence of tunnel size and nesting medium on sex ratios in a leaf-cutter bee, Megachile rotundata. Journal of Economic Entomology 58: 965-968.

Taylor DL, Hollingsworth TN, McFarland JW, Lennon NJ, Nusbaum C, Ruess RW (2014) A first comprehensive census of fungi in soil reveals both hyperdiversity and fine-scale niche partitioning. Ecological Monographs 84: 3-20.

Tepedino VJ, Parker FD (1986) Effect of rearing temperature on mortality, second-generation emergence, and size of adult in Megachile rotundata (Hymenoptera: Megachilidae). Journal of Economic Entomology 79: 974-977.

Thorp RW, Horning DS, Dunning LL (1983) Bumble bees and cuckoo bumble bees of California (Hymenoptera, Apidae) (Vol. 23). University of California Press, Berkeley. 
Tscharntke T, Gathmann A, Steffan-Dewenter I (1998) Bioindication using trap-nesting bees and wasps and their natural enemies: community structure and interactions. Journal of Applied Ecology 35: 708-719.

Tylianakis JM, Klein AM, Tscharntke T (2005) Spatiotemporal variation in the diversity of Hymenoptera across a tropical habitat gradient. Ecology 86: 3296-3302.

Tylianakis JM, Tscharntke T, Lewis OT (2007) Habitat modification alters the structure of tropical host-parasitoid food webs. Nature 445: 202-205.

Wcislo WT (1996) Parasitism rates in relation to nest site in bees and wasps (Hymenoptera: Apoidea). Journal of Insect Behavior 9: 643-656.

Wcislo WT, Cane JH (1996) Floral resource utilization by solitary bees (Hymenoptera: Apoidea) and exploitation of their stored foods by natural enemies. Annual Review of Entomology 41: $257-286$.

White J, Son Y, Park YL (2009) Temperature-dependent emergence of Osmia cornifrons (Hymenoptera: Megachilidae) adults. Journal of Economic Entomology 102: 2026-2032.

Williams NM, Crone EE, Roulston TH, Minckley RL, Packer L, Potts SG (2010) Ecological and life-history traits predict bee species responses to environmental disturbances. Biological Conservation 143: 2280-2291.

Willmer PG, Corbet SA (1981) Temporal and microclimatic partitioning of the floral resources of Justicia aurea amongst a concourse of pollen vectors and nectar robbers. Oecologia 51: $67-78$.

Yocum GD, Kemp WP, Bosch J, Knoblett JN (2005) Temporal variation in overwintering gene expression and respiration in the solitary bee Megachile rotundata. Journal of Insect Physiology 51: 621-629. 


\section{Table}

Table 1. Parasite-host associations determined post-emergence as recorded from trap nests in the study region over the three years of sampling. 'Days' represents the difference in mean emergence day between the parasite and the host. For parasites having more than one host, 'Days' was calculated for each parasite-host pair.

\begin{tabular}{lllcl} 
Parasite & Family & Order & Days & Hosts \\
\hline Sapyga louisi Krombein & Sapygidae & Hymenoptera & +7.7 & Heriades carinata \\
Sapyga centrata Say & Sapygidae & Hymenoptera & +0.1 & Osmia pumila \\
Ephialtes manifestator (Linnaeus) & Ichneumonidae & Hymenoptera & -2.7 & Passaloecus gracilis, \\
& & & +3.1 & Passaloecus cuspidatus, \\
& & & -1.7 & Trypoxylon frigidum \\
Perithous divinator (Rossi) & Ichneumonidae & Hymenoptera & -3.6 & Psenulus pallipes \\
Chrysis cembricola Krombein & Chrysididae & Hymenoptera & -0.6 & Symmorphus canadensis \\
Caenochrysis doriae (Gribodo) & Chrysididae & Hymenoptera & +2.8 & Trypoxylon frigidum \\
Caenochrysis tridens (Lepeletier) & Chrysididae & Hymenoptera & -7.7 & Trypoxylon collinum \\
Nemognatha piazata (Fabricius) & Meloidae & Coleoptera & -4.3 & Megachile rotundata \\
Anthrax irroratus Say & Bombyliidae & Diptera & +24.2 & Osmia caerulescens,
\end{tabular}




\section{Figure Captions}

Figure 1. A trap nest used to study cavity-nesting bees and wasps. The cardboard paper 'nesting tubes' are inserted into a piece of pink insulation board fitted into a white PVC pipe for support and protection from rain.

Figure 2. Variation in the mean emergence time for species of bee, wasp, and parasite recorded from individuals taken from trap nests. 'Taxa' denotes cavity-nesting bees (B), cavity-nesting wasps $(\mathrm{W})$, and parasites $(\mathrm{P})$. 'Abd' is the total number of individuals incubated and emerged successfully. 'Mean' is the average number of days taken to emerge and 'SE' is the standard error of the mean. Significant differences between species ('sig') were given alphabetically where species sharing a letter were not significantly different from one another $(\alpha=0.05)$. Those species denoted with a "+" are considered introduced to the region.

Figure 3. Scatterplot illustrating a significantly positive community-wide correlation between intraspecific mean and variation in emergence time.

Figure 4. Scatterplot showing the significant relationship between mean emergence time and body size as measured by the intertegular width. 